\title{
From Gnosticism to Agnotology: A Reply to Robertson and Talmont-Kaminski
}

\author{
LEONARDO AMBASCIANO
}

I confess I had second thoughts about my précis of An Unnatural History of Religions (henceforth AUHR) for Religio. ${ }^{1}$ Considering how nasty the reaction of the History of Religions (HoR hereafter) can be when it comes to criticism and scientific proposals, ${ }^{2}$ at a certain point between submission and copyediting I suddenly realized I might have made a professional faux pas. However, there was no point in panicking or hiding my head in the sand - the book had already been out for quite some time at that point. So, I bit my tongue and I waited with a mix of curiosity and despair. When I finally read the commentaries on my book, I breathed a sigh of relief. It is immensely gratifying to have two interlocutors as thoughtful as David G. Robertson and Konrad Talmont-Kaminski on board. On top of that, the meticulous editorial management provided by the staff behind Religio (in particular, Aleš Chalupa, Michaela Ondrašinová, and Matthew Nicholls) makes me wonder if a researcher could really ask for more, and I am deeply thankful to all of them. Now, I would like to take this unhoped-for opportunity to engage further with the reviewers in this brilliant conversation and offer some helpful updates and clarifications for the interested reader.

\section{Manufacturing ignorance}

Since the publication of $A U H R$, I have co-authored an article in which, along with my colleague Thomas J. Coleman III, I tried to point out the epistemological issues that characterize the recent experimental turn of the

1 Leonardo Ambasciano, An Unnatural History of Religions: Academia, Post-truth and the Quest for Scientific Knowledge, London - New York: Bloomsbury 2019.

2 Leonardo Ambasciano, "Memoirs of an Academic Rōnin: Religious Studies and Mentorship in the Age of Post-Truth", forthcoming in Method and Theory in the Study of Religion.

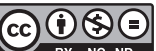

Religio: Revue pro religionistiku 28/1, 2020, 37-44.

https://doi.org/10.5817/Rel2020-1-4

This work can be used in accordance with the Creative Commons BY-NC-ND 4.0 International license terms and conditions (https://creativecommons.org/licenses/by-nc-nd/4.0/). 
Cognitive and Evolutionary Sciences of Religion (CSR and ESR) with regards to historiography. ${ }^{3}$ In the same vein, Robertson notes in his bold commentary that the CSR "can tend towards reifying certain discourses by disregarding their socio-historical contingencies". This is why I have tried to show in AUHR and elsewhere that a consilient and cross-disciplinary integration of just the very best CSR, ESR, sensu lato HoR, Religious Studies (RS), and other related disciplines can offer is not only possible but desirable for an epistemically warranted study of religion. ${ }^{4}$ Each one of these fields, if taken alone, is unable to make sense of the sheer complexity of human cultures and societies throughout time and space. ${ }^{5}$ Robertson concurs with me that "critical and cognitive approaches can work together in order to establish a post-colonial approach to the study of 'religion"'. Unfortunately, to say that our stance is a minority opinion in the field is an understatement.

Consider Robertson's current research on the history of Gnosticism as an academic concept. The case studies he briefly summarizes nicely complement my critical take in $A U H R$ and further testify to the disturbing cross-fertilization between pseudoscience, fideism, and esotericism that contributed to the creation of modern HoR. Having published a 600+ page-long monograph on the intellectual, political, and ideological background of Mircea Eliade's history of religions and his support of and engagement with all the major strands of anti-Enlightenment thought (including neo-creationism, esotericism, alchemy, Gnosis), I sympathize with Robertson's bleak view of the epistemologically flawed history of Gnosticism within and without HoR. ${ }^{6}$

Undaunted and faced with the epistemic defence mechanisms deployed by contemporary RS to shield the field from critical inquiry, Robertson pushes the envelope even further than I did, making a strong plea for the dissolution of $\mathrm{RS}$ as it represents another reservoir of pseudoscience and

3 Leonardo Ambasciano - Thomas J. Coleman, III, "History as a Canceled Problem? Hilbert's List, du Bois-Reymond's Enigmas, and the Scientific Study of Religion", Journal of the American Academy of Religion 87/2, 2019, 366-400.

4 E.g., Leonardo Ambasciano, "Who Is the Damiatrix? Ancient Roman Women, the Political Negotiation of Psychotropic Experiences, and the Cults of Bona Dea", in: Esther Eidinow - Armin W. Geertz - John North (eds.), Cognitive Approaches to Ancient Religious Experience, in preparation for Cambridge University Press.

5 Leonardo Ambasciano, "What Is Cognitive Historiography, Anyway? Method, Theory, and a Cross-Disciplinary Decalogue", Journal of Cognitive Historiography 4/2, 2017, 136-150.

6 Leonardo Ambasciano, Sciamanesimo senza sciamanesimo: Le radici intellettuali del modello sciamanico di Mircea Eliade: Evoluzionismo, psicoanalisi, te(le)ologia, Rome: Nuova Cultura 2014. Cf. Mircea Eliade, "Homo Faber and Homo Religiosus", in: Joseph M. Kitagawa (ed.), The History of Religions: Retrospect and Prospect, New York: MacMillan 1985, 1-12. 
fideism in academia: "perhaps, then, it is time to move past it". I had firsthand experience with this pseudoscientific incarnation of RS when I reviewed Kocku von Stuckrad's book The Scientification of Religion. ${ }^{7}$ In his rejoinder, von Stuckrad stated clearly that RS discursive approaches coexist symbiotically with the neo-Eliadean "New Sacred" heralded by Jeffrey J. Kripal and supported by renowned scholars in the field such as Ann Taves. ${ }^{8}$ It is worth recalling here that the New Sacred is a meta-pseudoscientific endeavour which "collects weird facts, paranormal stuff, and supernatural events, whatever their origins [from interspecies sexual intercourse with dolphins leading to the most peculiar telepathic exchanges to levitating and floating people], and that searches for overarching explanatory patterns in other kinds of pseudoscience". 9 Thus, any sympathetic approach towards the supernatural and the paranormal, as well as calls for a multiplicity (or "hybridity") of ways of knowledge as opposed to the sterility of mainstream science, are far from being neutral. These positions are complicit in the business of manufacturing ignorance.

The institutional situation hardly provides any relief to such predicaments. The latest British Academy report on Theology and Religious Studies (TRS) in the UK, released in 2019, has highlighted a plethora of problems that the disciplines grouped under this denomination are currently facing. Among the issues listed in the report one in particular stands out, that is, the downward "trend in enrolment onto TRS courses in UK higher education ..., in contrast to other humanities subjects like philosophy and history". ${ }^{10}$ While the report tentatively identifies a series of contextual causes (e.g., the rise of tuition fees), to date no critic has brought up the long-standing and internationally recognized issues behind the di-

7 Leonardo Ambasciano, "(Pseudo)science, Religious Beliefs, and Historiography: Assessing The Scientification of Religion's Method and Theory", Zygon 51/4, 2016, 1062-1066.

8 Kocku von Stuckrad, "The Hybridity of Scientific Knowledge: A Response to Leonardo Ambasciano", Zygon 51/4, 2016, 1067-1071. Cf. Ann Taves, "The Power of the Paranormal (and Extraordinary)", History of Religions 53/2, 2013, 205-211; the list of scholars who wrote enthusiastically about Kripal's books - whether in reviews or in blurbs - includes Tanya Luhrmann, Sarah Iles-Johnston, April DeConick, and Bron Taylor.

9 Leonardo Ambasciano, "Mind the (Unbridgeable) Gaps: A Cautionary Tale about Pseudoscientific Distortions and Scientific Misconceptions in the Study of Religion", Method and Theory in the Study of Religion 28/2, 2016, 141-225: 160; see also id., "Comparative Religion as a Life Science: William E. Paden's Neo-Plinian New Naturalism", Method and Theory in the Study of Religion 30/2, 2018, 141-149. Cf. Jeffrey J. Kripal, Comparing Religions, Malden, MA - Oxford: Wiley-Blackwell 2014.

10 The British Academy, "Theology and Religious Studies Provision in UK Higher Education" [online], <https://www.thebritishacademy.ac.uk/publications/theology-religious-studies-provision-uk-higher-education>, May 2019 [5 May 2020]. 
minishing stature of these fields in modern academia. ${ }^{11}$ As recalled by Robertson, there is simply no institutional push or disciplinary will to disengage from religious or spiritual interests, theological concerns, and political agendas, ${ }^{12}$ which is even more transparent in the following example. A recent Extended Executive Committee meeting of the first and most important governing body of the field, the International Association for the History of Religion (IAHR), was held in Delphi, Greece, 13-15 September 2019 , to discuss the potential change of the name of the association along with the possible insertion of an explicit reference to "the scientific study of religions" in the first article of its constitution. However, ambiguities and misgivings characterized the decision process, resulting in the mitigating addition of Religionswissenschaft[liche] to the article. Now, as explained in AUHR, Religionswissenschaft is a historical label used to define a specific group of early $20^{\text {th }}$-century, non-strictly scientific, and sometimes overtly anti-scientific, approaches to the comparative and historical study of religion. ${ }^{13}$ One step forward, two steps back.

\section{An exercise of agnotology}

In this sense, learning about the many extra-epistemic biases and interests behind the institutionalization of the study of religion(s) in modern academia becomes an exercise of agnotological research. Agnotology (from the Greek agnōsis, "not knowing") is the study of culturally- and politically-induced ignorance or doubt and the sister taxon of epistemology, and a case could easily be made for most branches within both HoR and RS to represent an institutional attempt to engender ignorance whether in good or in bad faith - by means of specific socio-cognitive strategies and mechanisms. ${ }^{14}$ With regards to these and other relevant issues, Talmont-Kaminski points out in his thought-provoking commentary that AUHR could and should have capitalized on the "excellent case study"

11 For a recent example of the misuse of RS tools to shield religiosity from critical inquiry in Religious Education in the UK, see John l'Anson - Alison Jesper, Schooling Indifference: Reimagining RE in Multi-Cultural and Gendered Spaces, London - New York: Routledge 2017. A rather different and more science-friendly approach is available in Tim Jensen, “'Jensen's Approach' to Religious Education”, CEPS Journal 9/4, 2019, 31-51.

12 Cf. Donald Wiebe, The Learned Practice of Religion in the Modern University, London - New York: Bloomsbury 2020; Juraj Franek, Naturalism and Protectionism in the Study of Religions, London - New York: Bloomsbury 2020.

13 "IAHR e-Bulletin Supplement: November 2019" [online], <http://www.iahrweb.org/ bulletins/IAHR_e-Bull_Suppl_Nov_2019.pdf>, [30 March 2020].

14 Robert N. Proctor - Londa Schiebinger (eds.), Agnotology: The Making and Unmaking of Ignorance, Stanford, CA: Stanford University Press 2008. 
provided by the history of the HoR as a "scientific failure on the borderlands with religion". In particular, Talmont-Kaminski notes that I was "unable to present the mechanisms at play in the discipline of the history of religion that allowed the ideas of Eliade to flourish where more scientific approaches did not take root". Although I recognize that epistemology has not been given an autonomous section in $A U H R$, I have nevertheless tackled this exact same problem in my 2018 Lakatosian analysis of Eliadean HoR as a degenerative research programme. ${ }^{15}$ I reference this contribution in $A U H R$, but I do see now that my failure to include it in extenso constitutes a potential source of unnecessary chagrin and misunderstanding.

I wholeheartedly concur with Talmont-Kaminski that we need a "meticulous study of human cognition in the wild, which should range from recognising general relationships, through identifying concrete cognitive and cultural mechanisms, all the way to tracing the detailed causal story behind particular historical cases". I can only add that I have recently tried to adopt something akin to this proposal in a cross-disciplinary decalogue for an updated incarnation of cognitive historiographical research. ${ }^{16} \mathrm{In}$ order to understand why I nonetheless deem such proposals to be inefficacious with respect to changing the course of already established fields such as HoR, RS, and, to a certain extent, CSR and ESR, I would like to expand upon Talmont-Kaminski's pertinent observations about "how the scientific study of religion could potentially be organized in the future", focusing in particular on qualitative historiography.

First of all, as Talmont-Kaminski himself knows well, disciplines like HoR and RS are perfectly fit to survive and thrive in the current post-truth information environment. ${ }^{17}$ For their part, CSR and ESR are equally prone to extra-epistemic "side-tracking" and ideological manipulation through private funding. In particular, the selective pressure exerted by pro-religious institutions has favoured the survival and success of pro-religious

15 Leonardo Ambasciano, "Politics of Nostalgia, Logical Fallacies, and Cognitive Biases: The Importance of Epistemology in the Age of Cognitive Historiography", in: Anders Klostergaard Petersen - Gilhus Ingvild Sælid - Luther H. Martin et al. (eds.), Evolution, Cognition, and the History of Religion: A New Synthesis, Leiden - Boston: Brill 2018, 280-296. See also id., "Mapping Pluto's Republic: Cognitive and Epistemological Reflections on Philosophy of Pseudoscience: Reconsidering the Demarcation Problem", Journal for the Cognitive Science of Religion 3/2, 2015, 183 205.

16 L. Ambasciano, "What Is Cognitive Historiography, Anyway?...".

17 Konrad Talmont-Kaminski, "Werewolves in Scientists' Clothing: Understanding Pseudoscientific Cognition", in: Massimo Pigliucci - Maarten Boudry (eds.), Philosophy of Pseudoscience: Reconsidering the Demarcation Problem, Chicago - London: University of Chicago Press 2013, 381-396. 
CSR and ESR research within the current neoliberal defunding of public higher education. ${ }^{18}$ On top of that, there are socio-cognitive constraints like Planck's Principle, potentially preventing any significant change to the status quo. ${ }^{19}$

To address such situations, we would need an ethically and epistemically warranted set of checks and balances. An inter-disciplinary methodology to review and support research in all these fields according to Virtue Epistemology and Virtue Ethics, ${ }^{20}$ Philosophy of Expertise,${ }^{21}$ Management Studies, ${ }^{22}$ and Evolutionary Epistemology ${ }^{23}$ would probably do the trick. Such a multifaceted method, inspired by recent Philosophy of Science responses to post-truth, fake news, and pseudoscience, ${ }^{24}$ would be particularly fit to take into consideration at the same time (1) the trustworthiness of the researchers and the reliability of their sources; (2) the epistemological commitments and the presence of extra-epistemic agendas behind both the institutional organization and the academic community environment in which the scholars work; (3) the theoretical justifications behind competing research programmes (RP); and (4) the cognitive and logical processes by which the members of this community make sense of their objects of study.

Now, this digression highlights even more the sheer "gargantuan task at hand" identified by Talmont-Kaminski. It is only fair to admit that the implementation of the meta-project presented above is unlikely to have

18 E.g., L. Ambasciano - T. J. Coleman III, "History as a Canceled Problem?...”.

19 Pierre Azoulay - Christian Fons-Rosen - Joshua S. Graff Zivin, "Does Science Advance One Funeral at a Time?”, American Economic Review 109/8, 2019, 28892920.

20 Daniel C. Russell (ed.), The Cambridge Companion to Virtue Ethics, Cambridge: Cambridge University Press 2013; John Turri - Mark Alfano - John Greco, "Virtue Epistemology" [online], in: Edward N. Zalta (ed.), The Stanford Encyclopedia of Philosophy: Fall 2019 Edition, <https://plato.stanford.edu/archives/fall2019/entries/ epistemology-virtue/>, 7 November 2017 [30 March 2020]; Nancy E. Snow (ed.), The Oxford Handbook of Virtue, Oxford: Oxford University Press 2018.

21 Evan Selinger - Robert P. Crease (eds.), The Philosophy of Expertise, New York: Columbia University Press 2006.

22 Mats Alvesson - André Spicer, The Stupidity Paradox: The Power and Pitfalls of Functional Stupidity at Work, London: Profile 2016.

23 Helen De Cruz - Maarten Boudry - Johan De Smedt - Stefaan Blancke, "Evolutionary Approaches to Epistemic Justification", Dialectica 65/4, 2011, 517-535; Michael Bradie - William Harms, "Evolutionary Epistemology" [online], in: Edward N. Zalta (ed.), The Stanford Encyclopedia of Philosophy: Spring 2020 Edition, <https://plato. stanford.edu/archives/spr2020/entries/epistemology-evolutionary/>, 21 January 2020 [30 March 2020]; see also Hugo Mercier - Dan Sperber, The Enigma of Reason: A New Theory of Human Understanding, London: Allen Lane 2017.

24 Massimo Pigliucci, Nonsense on Stilts: How to Tell Science from Bunk: Second Edition, Chicago - London: The University of Chicago Press 2018. 
any traction. Realistically speaking, who among those in charge would be willing to support such a progressive methodological problem shift knowing that it could spell their own demise? How could we be sure that the involvement of institutional watchmen from established and revered - but potentially flawed - fields won't bring about another regressive problem shift? Isn't this another Sisyphean struggle? Thus, for ethical, epistemological, and practical reasons, I maintain that it is better to invest our already strained resources into a cross-disciplinary, collaborative, all-new, all-different RP, rather than contributing to already established and problematic RPs from within their confines. ${ }^{25}$

In Lakatosian terms, AUHR has already provided a preliminary assessment of the most important RPs in the field and found most of them stagnating or degenerating. ${ }^{26}$ However, this does not mean that historiography is futile, though many CSR and ESR scholars have jumped to this hasty conclusion. ${ }^{27}$ Indeed, one of the goals of AUHR's pars construens was to show how relevant a handful of lato sensu HoR scholars and their seminal works can still be to current scientific conversations. ${ }^{28}$ As TalmontKaminski hints at in his conclusions, a "mature cognitive social science" cannot possibly do away with history and historiography, and a cognitive historiographical approach informed by History and Philosophy of Science may well help scholars to avoid the HoR/RS regressive problem shift, circumvent the presentist blunders of current CSR and ESR, and build a new, better, and progressive RP. This may break the camel's back in terms of acronyms, but anyone willing to collaborate, please RSVP!

25 Michael O'Rourke - Stephen Crowley - Chad Gonnerman, "On the Nature of CrossDisciplinary Integration: A Philosophical Framework", Studies in History and Philosophy of Science Part C, 56, 2016, 62-70; cf. Norman MacLeod, "Historical Inquiry as a Distributed, Nomothetic, Evolutionary Discipline", The American Historical Review 119/5, 2014, 1608-1620.

26 Cf. L. Ambasciano, "Politics of Nostalgia...".

27 Leonardo Ambasciano, "Exiting the Motel of the Mysteries? How Historiographical Floccinaucinihilipilification Is Affecting CSR 2.0", in: Luther H. Martin - Donald Wiebe (eds.), Religion Explained? The Cognitive Science of Religion after Twenty-Five Years, London - New York: Bloomsbury 2017, 107-122.

28 Cf. L. Ambasciano, "Comparative Religion as a Life Science...". 


\section{SUMMARY}

\section{From Gnosticism to Agnotology: A Reply to Robertson and Talmont-Kaminski}

This paper is a reply to the commentaries by David G. Robertson and Konrad TalmontKaminski on An Unnatural History of Religions: Academia, Post-truth and the Quest for Scientific Knowledge (2019) and published in this same issue of Religio: Revue pro religionistiku. Topics discussed herein include: the need for a consilient and cross-disciplinary research programme for cognitive historiography; pseudoscience in Religious Studies; the epistemological study of disciplinary ignorance-making (or Agnotology); and cross- and inter-disciplinary proposals to support an overhaul of the field's method and theory (i.e., Virtue Epistemology, Virtue Ethics, Philosophy of Expertise, Management Studies, Evolutionary Epistemology, Cognitive Historiography, History and Philosophy of Science).

Keywords: Agnotology; Cognitive Historiography; History and Philosophy of Science; History of Religions; pseudoscience; Religious Studies.

Journal of Cognitive Historiography Managing Editor

LEONARDO AMBASCIANO leonardo.ambasciano@gmail.com 